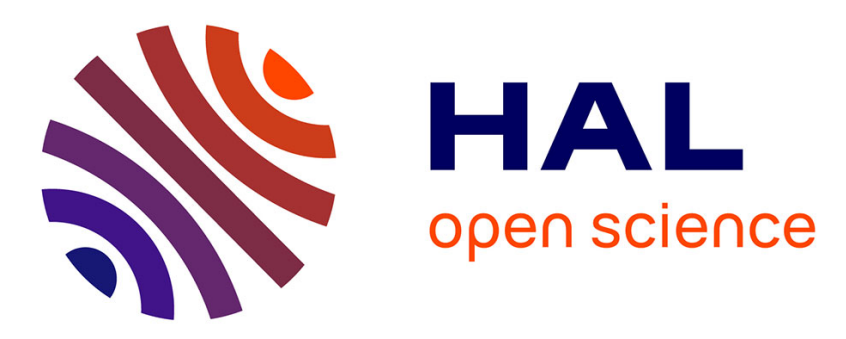

\title{
Synthesis and properties of barium diketonates as precursors for MOCVD
}

A. Drozdov, S. Troyanov, N. Kuzmina, L. Martynenko, A. Alikhanyan, I. Malkerova

\section{- To cite this version:}

A. Drozdov, S. Troyanov, N. Kuzmina, L. Martynenko, A. Alikhanyan, et al.. Synthesis and properties of barium diketonates as precursors for MOCVD. Journal de Physique IV Proceedings, 1993, 03 (C3), pp.C3-379-C3-384. 10.1051/jp4:1993352 . jpa-00251409

\section{HAL Id: jpa-00251409 https://hal.science/jpa-00251409}

Submitted on 1 Jan 1993

HAL is a multi-disciplinary open access archive for the deposit and dissemination of scientific research documents, whether they are published or not. The documents may come from teaching and research institutions in France or abroad, or from public or private research centers.
L'archive ouverte pluridisciplinaire HAL, est destinée au dépôt et à la diffusion de documents scientifiques de niveau recherche, publiés ou non, émanant des établissements d'enseignement et de recherche français ou étrangers, des laboratoires publics ou privés. 


\title{
Synthesis and properties of barium diketonates as precursors for MOCVD
}

\author{
A.A. DROZDOV, S.I. TROYANOV, N.P. KUZMINA, L.I. MARTYNENKO, A.S. ALIKHANYAN \\ and I.P. MALKEROVA \\ Department of Chemistry, Moscow State University, Moscow 119889, Russia
}

\begin{abstract}
The structures of barium diketonates depend on the way in which they are synthesized. It is shown that there is a correlation between the volatility of these compounds and their crystal structures. A new volatile mononuclear adduct of barium dipivaloylmethanate suitable for MOCVD is suggested.
\end{abstract}

Barium 2,2,6,6-tetramethylheptanedionate ( $\mathrm{Ba}(\mathrm{thd})_{2}$ ", also termed barium dipivaloylmethanate) is one of the best precursors for CVD of barium containing superconducting films. However, this compound has some undesirable properties: relatively low volatility, a progressive loss of its volatility in the temperature range used in MOCVD, and unstable storage characteristics. The composition of "Ba(thd) ${ }_{2}$ " depends upon the method of synthesis. Three different ways for its preparation are known:

- reaction between $\mathrm{Ba}(\mathrm{OH})_{2}$ and Hthd in aqueous solution (1)

$\mathrm{Ba}(\mathrm{OH})_{2}+2 \mathrm{Hthd} \longrightarrow \mathrm{Ba}_{5}(\text { thd })_{9}(\mathrm{OH})\left(\mathrm{H}_{2} \mathrm{O}\right)_{3}$

- interaction of $\mathrm{BaCl}_{2}$ or $\mathrm{Ba}\left(\mathrm{NO}_{3}\right)_{2}$ with Nathd in the aqueous ethanol (2)

$\mathrm{BaCl}_{2}+2 \mathrm{Nathd} \longrightarrow \mathrm{Ba}(\text { thd })_{2} \cdot 2 \mathrm{H}_{2} \mathrm{O}$ "

- by dissolving of barium metal in Hthd (3)

$\mathrm{Ba}+2 \mathrm{Hthd} \longrightarrow \mathrm{Ba}_{4}(\text { thd })_{8}$ (III).

The product I was investigated by Sievers and co-workers (1). It was shown that in the range of temperatures used in MOCVD 
the pentanuclear complex I progressively loses its volatility through partial decomposition to involatile species. In our work to synthesize barium dipivaloylmethanate we used the methods II(2) and III(3). According to the data of the elemental and thermal analyses complex II has the composition $\mathrm{Ba}(\mathrm{thd}){ }_{2} \cdot 2 \mathrm{H}_{2} \mathrm{O}$ and can be sublimed in vacuo $\left(220^{\circ} \mathrm{C}, 0.01\right.$ torr) practically without decomposition. However, during storage in a sealed tube this compound changes its sublimation properties. Apparently hydrolysis occurs, evolving Hthd and forming the involatile products. The tetranuclear compound III $(3,4)$ (a product obtained by reaction III) sublimes at the same temperature $\left(240^{\circ} \mathrm{C}\right)$ without giving any involatile residue.

The difference in the volatility of II and low volatility of $\mathrm{Ba}(\mathrm{hfa})_{2}$ (Hhfa- 1,1,1,5,5,5-hexafluoroacetylacetone) can be explained by the differences in their structures. It was supposed (5), that anhydrous $\mathrm{Ba}(\mathrm{hfa})_{2}$ " appears to be polymeric. As the structural data for the pure homoligand complex have not been reported the X-ray structure of the polymeric $\left[\mathrm{Ba}(\mathrm{hfa})_{2} \cdot 1 / 2 \mathrm{Et}_{2}{ }_{2}\right]_{n}$ (IV) we synthesized recently is of great interest. The crystals of IV were obtained by the reaction of barium metal with Hhfa in pentane-ether solution. It was found that IV consists of the infinite zig-zag chains of the barium atoms linked by the bridging tri- or tetradentate hfa-anions. A characteristic feature of this structure is the additional coordination of the fluorine atoms from the $\mathrm{CF}_{3}$-groups of hfa to the barium atoms (fig. 1). Obviously, these $B a-F$ interactions are responsible for the formation of barium fluoride as a decomposition product. The structure as a whole is very similar to that recently reported for $\left[\mathrm{Ba}(\mathrm{hfa}){ }_{2} \mathrm{H}_{2}{ }^{\mathrm{O}]}{ }_{\mathrm{n}}(6)\right.$. It is important to note that some other barium complexes with the fluorinated ligands (e.g. $\mathrm{C}_{3} \mathrm{H}_{7} \mathrm{C}(0) \mathrm{CH}_{2} \mathrm{C}(\mathrm{O}) \mathrm{C}_{3} \mathrm{H}_{7}$ (7), appear to be much more volatile than $\mathrm{Ba}(\mathrm{hfa})_{2}$. However, their crystal structures have not been studied yet.

To investigate $\mathrm{Ba}_{4}$ (thd) $_{8}$ in the vapour phase mass-spectrometry was used. The resublimed product was studied by this method in the temperature range $160-185^{\circ} \mathrm{C}$ which corresponds to the sublimation of the complex. At higher temperatures $\mathrm{Ba}_{4}(\text { thd })_{8}$ 
melts. The electronic ionization mass-spectra showed peaks at $\mathrm{m} / \mathrm{z}$ ratios 1329, 825 and 321 corresponding to $\mathrm{Ba}_{3} \mathrm{thd}_{5}{ }^{+}, \mathrm{Ba}_{2}$ thd ${ }^{+}$and Bathd $^{+}$respectively. For the investigation of the saturated vapour pressure a Knudson method was used (Table 1).

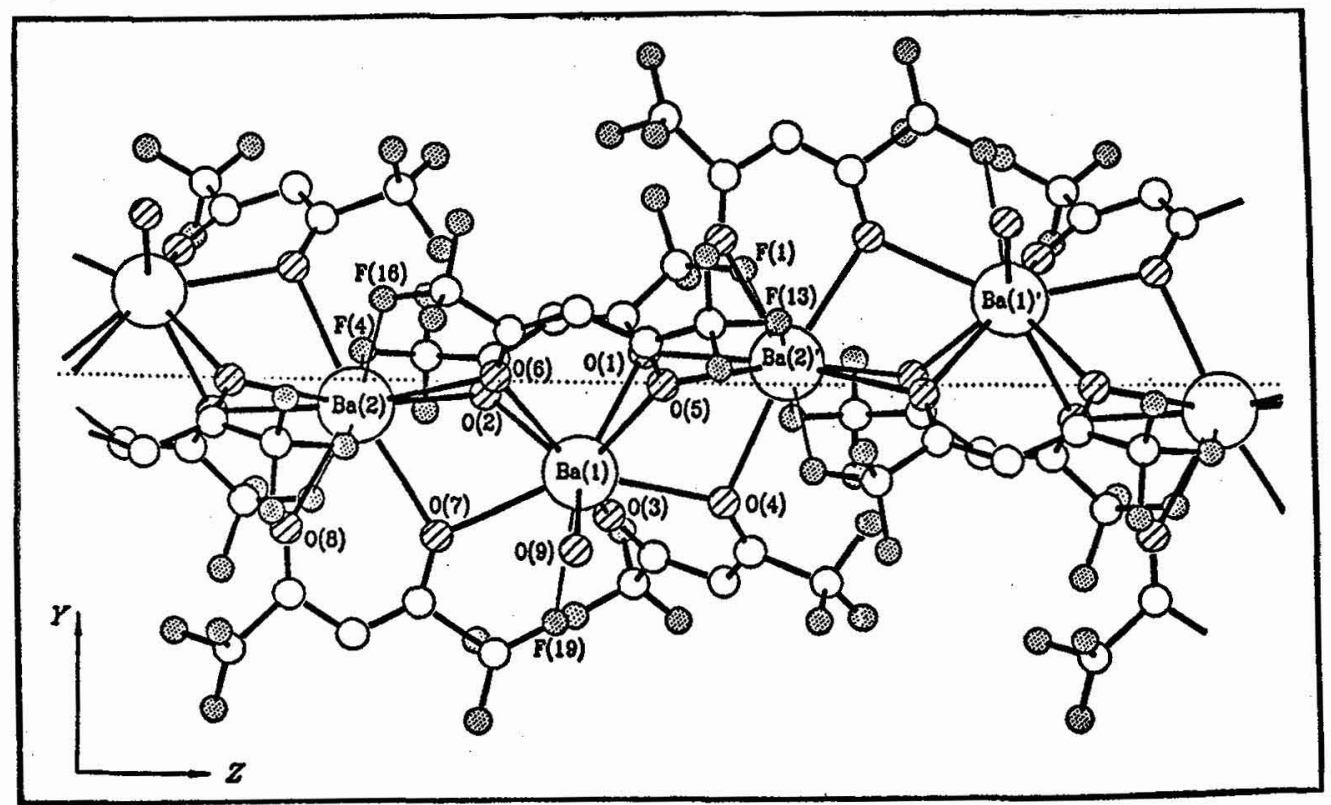

Fig. 1. YZ-Projection of the structure $\left[\mathrm{Ba}(\mathrm{hfa})_{2} \cdot 1 / 2 \mathrm{Et}_{2}{ }^{0]} \mathrm{n}\right.$.

Table 1.

The composition of $\mathrm{Ba}_{4}$ thd 8 saturated vapour according to mass-spectrometry.

\begin{tabular}{|c|ccc|}
\hline \multirow{2}{*}{ Temperature, $K$} & \multicolumn{3}{|c|}{ Partial vapour pressure, atm } \\
\cline { 2 - 4 } & Bathd & $\mathrm{Ba}_{2}$ thd $_{4}$ & $\mathrm{Ba}_{3}$ thd $_{6}$ \\
\hline 425 & $2.9 \times 10^{-11}$ & $1.2 \times 10^{-9}$ & $4.2 \times 10^{-7}$ \\
441 & $1.7 \times 10^{-10}$ & $8.4 \times 10^{-9}$ & $4.2 \times 10^{-7}$ \\
\hline
\end{tabular}


From these data it appears that the trinuclearspecies have highest partial vapour pressure. The ions with the higher mass cannot be observed due to the low scanning facility of the spectrometer used. It is very likely that a saturated vapour of $\mathrm{Ba}_{4} \mathrm{thd}_{8}$ also contains the tetranuclear species. A correlation between the vapour pressure of the trimeric form and temperature was determined:

$$
\operatorname{lgP}_{\mathrm{Ba}_{3} \mathrm{thd}_{6}}(\mathrm{~mm} \mathrm{Hg})=-\frac{10900}{\mathrm{~T}}+21.22 .
$$

The enthalpies of the dissociation processes in vapour were calculated:

$$
\begin{array}{ll}
{ }_{2 \mathrm{Ba}_{3} \mathrm{thd}_{6}} \longrightarrow{ }_{3 \mathrm{Ba}_{2} \mathrm{thd}_{4}} & \Delta_{\mathrm{D}} \mathrm{H}_{\mathrm{T}}^{\mathrm{O}}=38.0 \mathrm{kcal} / \mathrm{mol} \\
\mathrm{Ba}_{2} \mathrm{thd}_{4} \longrightarrow \text { Bathd }_{2} & \Delta_{\mathrm{D}} \mathrm{H}_{\mathrm{T}}^{\mathrm{O}}=39.5 \mathrm{kcal} / \mathrm{mol} .
\end{array}
$$

The values of sublimation enthalpies for $\mathrm{Ba}_{3} \mathrm{thd}_{6}, \mathrm{Ba}_{2} \mathrm{thd}_{4}$ and $\mathrm{Ba}_{4}$ thd $_{8}$ are $49.9,46.1$ and $42.8 \mathrm{kcal} / \mathrm{mol}$ respectively.

The volatility of barium diketonates can be increased by the depolimerization of the oligomeric species.

One of the ways to affect the structure (and consequently the volatility) of barium diketonates is the synthesis of mixed ligand complexes containing both diketonate and anionic or neutral additional ligands. As a rule, the use of the anionic additional ligands does not diminish the degree of oligomerization. Thus, the presence of the hydroxy (1) or pivalate (3) anions results in the pentanuclear complexes $\mathrm{Ba}_{5}$ (thd) $\mathrm{X}, \mathrm{X}=\mathrm{OH}$, piv. Our preliminary results show that the product of the reaction II contains a pentanuclear $\mathrm{Ba}_{5}$ (thd) ${ }_{9} \mathrm{Cl}$, the structure being similar to that mentioned above. The formation of such compounds, generally, does not influence the sublimation parameters.

The use of neutral $\mathrm{N}$ - and 0 - additional ligands leads to a decrease in the degree of oligomerization down to the dinuclear or mononuclear species (8-11). Anew exampleof a dinuclear adduct is the complex with 2,2'-dipyridyl $\mathrm{Ba}_{2}$ (thd) ${ }_{4}$ (dipy) 2 (V, fig.2), being similar to the ammonia complex $\mathrm{Ba}_{2}(\text { thd })_{4}\left(\mathrm{NH}_{3}\right)_{4}$ (12). To 


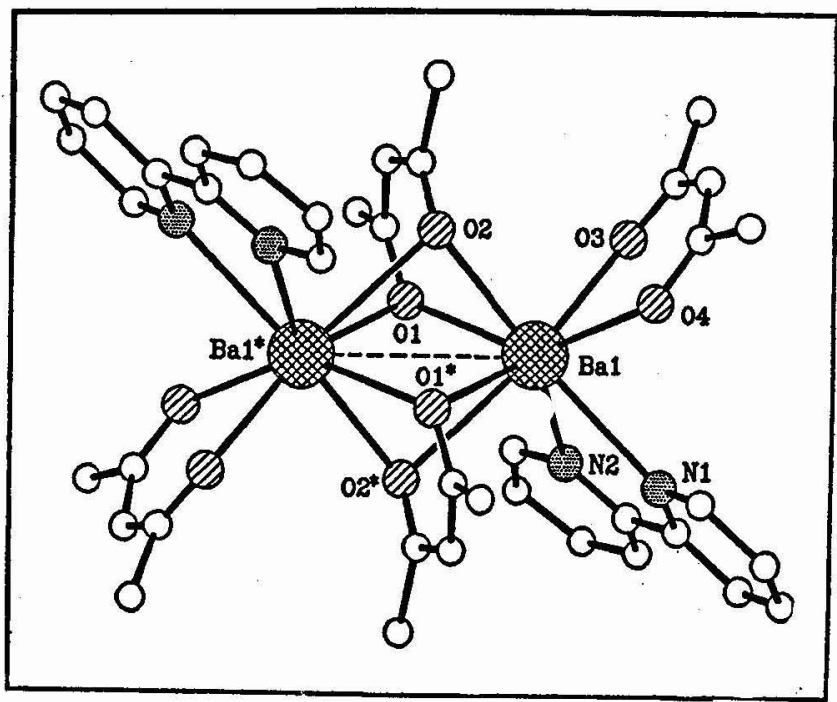

Fig.2. A perspective view of $\mathrm{Ba}_{2}$ (thd $)_{4}(\text { dipy })_{2}$. The terminal carbon atoms from the $t-B u$ groups are omitted.

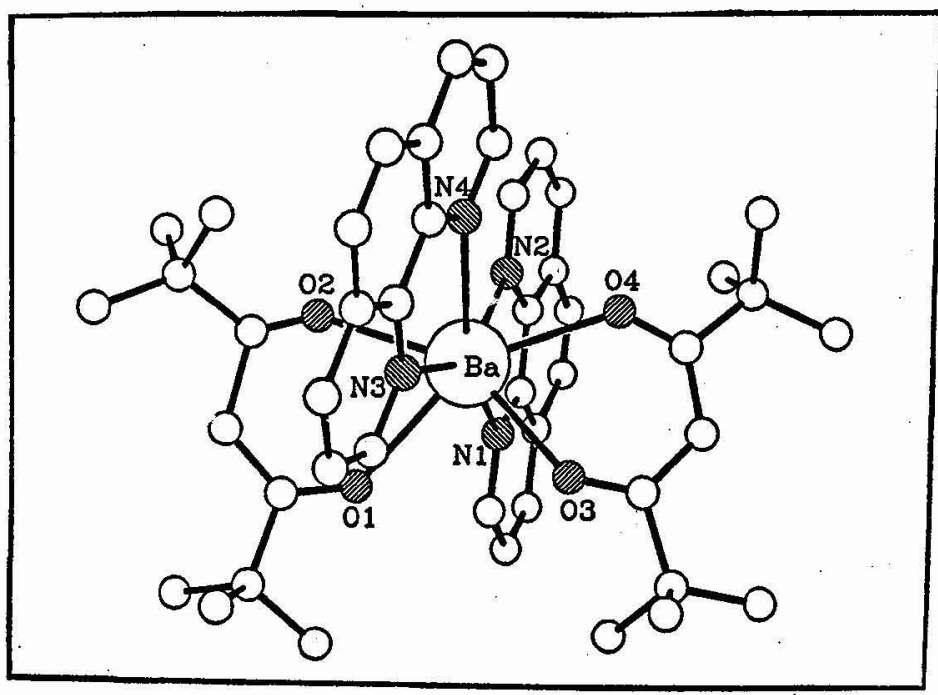

Fig. 3. A perspective view of $\mathrm{Ba}(\text { thd })_{2}$ (phen) $_{2}$. 
obtain a mononuclear complex an excess of the additional ligand must bejused. Thus, the reaction of

$\mathrm{Ba}_{4}$ (thd) 8 with o-phenanthroline ( phen) in benzene solution resulted in the anhydrous product $\mathrm{Ba}(\mathrm{thd})_{2}(\mathrm{phen})_{2}$ (VI, fig. 3 ). As the coordination number of barium in VI is rather high and both chelate ligands are bulky, this compound possesses high volatility (at $200^{\circ} \mathrm{C}, 0.01$ torr with the decomposition to $\mathrm{Ba}_{4}$ (thd) $_{8}$ and phen) and can be endless stored on the air.

Thus, the use of the additional ligands makes it possible to decrease the temperature of sublimation and to improve the storage stability.

References.

[1] TURNIPSEED S.B., BARKLEY R.M., SIEVERS, R.E., Inorg. Chem. 30 (1991), 1164.

[2] KUZMINA N.P., ZAITSEVA I.G. et al, Zh. Neorgan. Khim. 36 (1991), 2739.

[3] DROZDOV A.A., TROYANOV S.I., Polyhedron (1992), 11, 2877.

[4] ALAIN G., SANDRINE S.L., DOMINIQUE M., C.R. Acad. Sci., 313, (1991), 761.

[5] PURDY A.P., BERRY A.D., HOLM R.T., FATEMI M., GASKILL D.K., Inorg. Chem. 28 (1989), 2799.

[6] BRADLEY D.C., HASAN M., Hursthouse M.B., Motevalli M., Khan 0.F.Z., Pritchard R.G., Williams Y.0, J. Chem. Soc., Chem. Commun., (1992), 575.

[7] THOMPSON S.C., COLE-HAMILTON D.J., GILLILAND D.D., HITCHMAN M.L., BAMES J.C., Advanced Materials for optics and Electronics, 1 (1992), 81

[8] SLUIS P., SPEK A.L., TIMMER K., MEINEMA H.A., Acta Cryst., C46 (1990), 1741.

[9] TIMMER K., MEINEMA H., Inorg. Chim. Acta, 187 (1991), 99. [10] NORManN Y.A.T., PEZ G.P., J. Chem. Soc., Chem. Commun., (1991), 971.

[11] DROZDOV A., KUZMINA N., TROYANOV S., MARTYNENKO L., Materials Science and Engineering, B18 (1993), 139.

[12] REES W.S., CARRIES M.W., HESSE W., Inorg. Chem., 30 (1991), 4479 . 